\title{
COMPLICATIONS OF SURGICAL TREATMENT OF LUMBAR STENOSIS IN THE EARLY POSTOPERATIVE PERIOD
}

\author{
COMPLICACCÕES DO TRATAMENTO CIRÚRGICO DA ESTENOSE LOMBAR NO PERÍODO \\ PÓS-OPERATÓRIO IMEDIATO
}

\author{
COMPLICACIONES DEL TRATAMIENTO QUIRÚRGICO DE LA ESTENOSIS LUMBAR \\ EN EL PERÍODO POSTOPERATORIO TEMPRANO
}

Igor Vadimovich Basankin¹,2, Vladimir Alexeevich Porkhanov ${ }^{1,2}$, Asker Alievich Afaunov ${ }^{1},{ }^{2}$, AleXander Veniaminovich Kuzmenko ${ }^{1}$,
Vladimir Konstantinovich Shapovalov ${ }^{1}$

1. Research Institute Krasnodar Regional Hospital 1, Krasnodar, Russia .

2. Kuban State Medical University, Krasnodar, Russia.

\begin{abstract}
Objective: To analyze the structure of degenerative lumbar stenosis surgical treatment complications and to analyze their effect on the results and indications for revision operations. Methods: Between 2009 and 2013, 513 patients with lumbar stenosis of degenerative etiology were surgically treated. There were 205 men, 308 women, aged 23 to 74 years. The main clinical manifestations were persistent compression radiculopathy, chronic pain in the back and lower limbs, and difficulty walking. The intensity of the pain was assessed by the VAS. At the time of hospitalization, VAS was 55-90 points. Results: Of the 513 operated patients, 65 (12.67\%) had complications in the early postoperative period (up to three months after the operation); intraoperative complications occurred in 26 (5.1\%) patients; intraoperative dura mater injury occurred in 24 (4.67\%); pulmonary embolism (PE) occurred in 2 (0.39\%) patients; 39 patients had early postoperative complications; acute radiculopathy occurred in 22 patients (4.28\%); and 17 patients (3.31\%) had surgical wound complications. Conclusions: Liquorrhea, postoperative hematomas and acute radiculopathy had no negative effect on the results of treatment in any of the cases. In the early postoperative period, $4(0.77 \%)$ deaths were recorded intraoperatively and in $2(0.39 \%)$ cases, intraoperative PE occurred. Two cases $(0.39 \%)$ resulted in sepsis and multiple organ failure. In eight $(1.55 \%)$ patients, the results of the treatment were unsatisfactory: in 4 $(0.77 \%)$ cases due to death, and in a further $4(0.77 \%)$ due to elimination of the system by the spinal column as a result of suppuration. Level of Evidence IV; Therapeutic studies - Investing the results of treatment.
\end{abstract}

Keywords: Spinal stenosis; Postoperative period/complications; Suppuration.

\section{RESUMO}

Objetivo: Analisar a estrutura das complicações do tratamento cirúrgico da estenose lombar degenerativa e analisar seu efeito nos resultados e indicações para operações de revisão. Métodos: Nos anos de 2009-2013, 513 pacientes com estenose lombar de etiologia degenerativa foram tratados cirurgicamente. Havia 205 homens, 308 mulheres com idades entre 23 e 74 anos. As principais manifestações clínicas foram radiculopatia por compressão persistente, dor crônica nas costas e membros inferiores, dificuldade para andar. A intensidade da dor foi avaliada pela EAV. No momento da hospitalização, a EVA foi de 55 a 90 pontos. Resultados: Entre os 513 pacientes operados, 65 (12,67\%) tiveram complicações do pós-operatório imediato (até três meses após a operação ocorreram complicações intraoperatórias em 26 (5,1\%) pacientes. A lesão intra operatória da dura-máter ocorreu em 24 (4,67\%); embolia pulmonar (EP) ocorreu em dois (0,39\%) pacientes, 39 pacientes com complicações pós-operatórias precoces, radiculopatia aguda em 22 pacientes (4,28\%) e 17 pacientes (3,31\%) com complicações da ferida. Os hematomas pós-operatórios e a radiculopatia aguda tiveram efeito negativo sobre os resultados do tratamento em nenhum caso. No período pós-operatório imediato, 4 (0,77\%) dos óbitos foram registrados no período intra operatório e em dois (0,39\%) casos o PE intra operatório. Em dois casos (0,39\%) foram motivo de sepse e falência múltipla de órgãos, sendo que em oito (1,55\%) pacientes foram encontrados resultados insatisfatórios: em quatro $(0,77 \%)$ devido à morte - e em quatro devido à remoção dos sistemas da coluna por causa de supuração. Nível de Evidência IV; Estudos terapêuticos - investigação dos resultados do tratamento.

Descritores: Estenose espinal; Período pós-operatório/complicações; Supuração.

\section{RESUMEN}

Objetivo: Analizar la estructura de las complicaciones del tratamiento quirúrgico de la estenosis lumbar degenerativa y analizar su efecto sobre los resultados y las indicaciones para las operaciones de revisión. Métodos: En 2009-2013 513 pacientes con estenosis lumbar de etiología degenerativa fueron tratados quirúrgicamente. Hubo 205 hombres, 308 mujeres, de 23 a 74 años. Las principales manifestaciones clínicas fueron radiculopatía por compresión persistente, dolor crónico en la espalda y las extremidades inferiores, y dificultades para caminar. La intensidad del dolor fue evaluada por EVA. En el momento de la hospitalización, la EVA tenía 55-90 puntos. Resultados: Entre los 513 pacientes operados, 65 (12,67\%) tuvieron complicaciones en el período postoperatorio temprano (hasta tres meses después de la operación); hubo complicaciones intraoperatorias en 26 (5,1\%) pacientes; lesión duramadre intraoperatoria ocurrió en 24 (4,67\%); embolia pulmonar (EP) se presentó en dos pacientes (0,39\%); hubo 39 pacientes con complicaciones postoperatorias tempranas; en 22 (4,28\%)

Study conducted at the Krasnodar Regional Hospital 1, Krasnodar, Russia.

Correspondence: Krasnodar, Russia. 1 may str. 167. 350086. basankin@ rambler.ru 
radiculopatía aguda y en 17 (3,31\%) complicaciones en la herida. Conclusiones: Liquorrea, hematomas postoperatorios y la radiculopatía aguda no tuvieron efecto negativo en los resultados del tratamiento en ninguno dos casos. En el período postoperatorio temprano se registraron cuatro $(0,77 \%)$ muertes intraoperatorias y en dos $(0,39 \%)$ casos se trató de una $P E$ intraoperatoria. Dos casos $(0,39 \%)$ resultaron en sepsis y falla orgánica múltiple. Se observaron resultados de tratamiento insatisfactorios en ocho (1,55\%) pacientes: en 4 (0,77\%) debido a la muerte, y en cuatro (0,77\%) - debido a eliminación del sistema por la espina dorsal debido a supuración. Nivel de evidencia IV; Estudios terapéuticos - Investigación de los resultados del tratamiento.

Descriptores: Estenosis Espinal; Periodo Posoperatorio/complicaciones; Supuración.

\section{INTRODUCTION}

Lumbar stenosis of degenerative etiology is one of the most common causes of progressive functional deadaptation of the spine. According to the literature, ${ }^{1-6}$ lumbar stenosis occurs in 6 to $15 \%$ of patients with chronic back pain. The averaged number of annual operations for lumbar stenosis in Western Europe is 114-132 per $1,000,000$ people. ${ }^{4}$ There are various surgical approaches aimed at eliminating degenerative spinal stenosis, but the choice of technique is still a matter of debate., Dorsal root decompression in combination with transpedicular fixation and interbody spondylodesis, performed via posterior or posterolateral access to the intervertebral discs (PLIF or TLIF), has recently become widespread.

The effectiveness of surgical treatment for certain forms of degenerative lumbar stenosis is beyond doubt. However, the complications of such operations are as high as $20 \% .^{2,7}$ Complications in the early postoperative period include a worsening of the vertebrogenic algic syndrome, postoperative liquorrhea, and suppuration of the operating wound. Complications in the later postoperative period include instability of fixation structures, late suppuration, and progression of dystrophic processes to adjacent vertebral motor segments. ${ }^{8,9}$ In some cases, these complications can be easily eliminated and do not affect the results of the treatment. In others, the complications may necessitate revision surgery, with a negative impact on the results, and even mortality. The aim of this study was to analyze the structure of degenerative lumbar stenosis surgical treatment complications, their effect on the results, and indications for revision operations.

\section{METHODS}

Between 2009 and 2013, 513 patients with lumbar stenosis of degenerative etiology were surgically treated. The protocol of acceptance in the Ethics Committee n. 27. An Informed Consent Form was signed by all the participants. There were 205 men and 308 women, with ages from 23 to 74 years. All patients had had the disease more than 5 years. The main clinical manifestations at the time of treatment in the clinic were persistent compression radiculopathy, chronic pain in the back and lower limbs, and difficulty walking. The intensity of the pain was assessed by the VAS. At the time of hospitalization, the VAS was 55-90 points. The functional deadaptation was scored using the Oswestry Low Back Pain Disability Questionnaire (ODI). ${ }^{2}$ In all patients, the diagnosis was confirmed by MRI and/or CT. In all cases, there were combined morphological causes of narrowing of the vertebral, lateral and foraminal canals. The concomitant somatic pathology, which required preclinical preoperative preparation, was recorded in 95 (18.6\%) patients.

\section{RESULTS}

The immediate treatment within three months after operations were studied in 493 (96.1\%) patients. Elimination of the clinical manifestations of radiculopathy and back pain (VAS 0-5 points) was completely achieved in 229 (46.45\%) patients. Another 178 (36.1\%) patients noted the absence of manifestations of radicular syndromes while continuing to have low back pain on physical exertion (VAS to 20 points). A significant reduction in radicular pain and low back pain (VAS 20-35 points) was achieved in 86 (17.44\%) patients. Life indicators of these patients improved significantly, and the pain was scored according to the Oswestry Low
Back Pain Disability Questionnaire (with scores improving by an average of 48 points). Of the 513 operated patients, 65 (12.67\%) had complications in the early postoperative period (up to three months after the operation).

There are 26 complications, 2 PE and 24 dura mater injurys. Dmong the 24 injurys of the dura mater, which we took as $100 \%$ (24 wounds), 11 of 24 (45.83\%) patients had dura mater injury during TLIF or PLIF. These injuries occurred in cases where there was epidural fibrosis that, in our opinion, was a consequence of previous surgery (6 cases), or of an extended period of vertebral disc-radicular conflict (five cases). In 13 (54.16\%) patients, the intraoperative dura mater injuries could be explained by technical difficulties associated with decompression at a critical value of combined degenerative stenosis.

If the injuries were in the visual inspection area, the defect was sutured. If the injuries were out of sight, they were sealed using Bioglue. Liquorrhea was successfully eliminated in 14 (58.33\%) cases out of $24(100 \%)$. In $10(41.67 \%)$ patients, it was not possible to completely eliminate the liquorrhea. In these situations, patients were prescribed antibacterial therapy. Drainage tubes were left in for up to 4-5 days after surgery, and the small holes left after their removal were closed tightly as by suturing. In 7 cases, this technique successfully prevented seepage of cerebrospinal fluid. In 3 patients, cerebral spinal fluid continued to seep through the drainage holes. In these patients, lumbar cerebral drainage was inserted for four to six days and the wound was re-sutured. Thus, in all ten patients, the liquorrhea was eliminated in the early postoperative period. Intraoperative massive pulmonary embolism occurred in $2(0.39 \%)$ patients during the completion of the final stage of four-segment TLIF, resulting in the deaths of the patients. It should be noted that fatal intraoperative PE was recorded in patients who did not have high risk factors against a background of standard preventive therapy.

There were 39 patients with early postoperative complications. Acute radiculopathy occurred in 22 patients (4.28\%). These 22 cases of postoperative radiculopathy were taken as 100\%. In 19 (86.36\%) patients, it was eliminated with conservative therapy combined with physiotherapy and exercise therapy. The conservative treatment was ineffective in 3 patients (13.60\%). CT and/or MRI revealed the cause of acute radicular syndrome: in $2(9 \%)$ cases it was caused by incorrectly implanted screws; in one (4.54\%) case, the osteophytic articular facet was not completely removed. Revision decompressive operations were performed, eliminating the radiculopathy. The complications had no effect on the results.

In 17 patients (3.31\%), there were wound complications. In three patients $(0.58 \%)$ a hematoma formed at the surgical site, necessitating a revision surgery. Suppuration of the surgical wound in the early postoperative period occurred in $14(2.72 \%)$ patients. Stepwise surgery, step-by-step included necroctomy, active drainage of the wound with vacuum dressings, and replacement and subsequent application of secondary sutures. In $2(0.38 \%)$ patients, wound suppuration occurred in the early postoperative period following the TLIF, which was performed in three and four spinal segments, causing sepsis, bilateral pneumonia and multiple organ failure. Early suppuration was stopped and the metal construction was saved in $10(71.42 \%)$ out of the $14(100 \%)$ cases. In $4(28.58 \%)$ cases, removal of metal construction was required, and in $2(14.28 \%)$ cases, the metal construction was removed as a result of generalization of wound infection. 


\section{DISCUSSION}

The most dangerous intraoperative complications in the early postoperative period leading to lethal outcomes were PE and suppuration of the postoperative wound, followed by generalization of wound infection leading to sepsis. Complications in the early postoperative period leading to unsatisfactory treatment results were suppuration of the operating wound, with early destabilization of the metal fixators and their removal. Other complications (liquorrhea, acute radiculopathy, postoperative hematomas, and early suppuration without destabilization of the spinal system) did not adversely affect the results of treatment, although in some cases, they served as indications for revision operations.

\section{CONCLUSION}

Liquorrhea, postoperative hematomas and acute radiculopathy had no negative effect on the results of treatment in any of the cases. In the early postoperative period, four $(0.77 \%)$ deaths were recorded intraoperatively. Two $(0.39 \%)$ cases were due to an intraoperative PE. Two cases (0.39\%) were due to sepsis and multiple organ failure. Unsatisfactory treatment results were observed in eight (1.55\%) patients: in $4(0.77 \%)$ due to death, in $4(0.77 \%)$ due to removal of the spinal system as a result of suppuration.

All authors declare no potential conflict of interest related to this article.

CONTRIBUTION OF THE AUTHORS: Each author made significant individual contributions to this manuscript. IVB $(0000-0003-3549-0794)^{\star}$ and VAP $(0000-0003-2732-2133)^{\star}$ were the main contributors to the drafting of the manuscript. IVB, AAA (0000-0001-7976-860X)*, AVK $(0000-0002-2741-7338)^{\star}$, VKS $(0000-0003-4556-251 X)^{*}$ performed the surgery, followed up the patients, and gathered clinical data. VKS evaluated the data from the statistical analysis. AAA, AVK and VAP performed the literature search and review of the manuscript, and contributed to the intellectual concept of the study. ${ }^{*} \mathrm{ORCID}$ (Open Researcher and Contributor ID).

\section{REFERENCES}

1. Airaksinen O, Brox JI, Cedraschi C, Hildebrandt J, Klaber-Moffett J, Kovacs F et. al. Chapter 4 . European guidelines for the management of chronic nonspecific low back pain. Eur Spine J. 2006;15(Suppl. 2):S192-300.

2. Mirza SK, Deyo RA. Systematic review of randomized trials comparing lumbar fusion surgery to nonoperative care for treatment of chronic back pain. Spine (Phila Pa 1976). 2007;32(7):816-23

3. Breivik, Collett B, Ventafridda V, Cohen R, Gallacher D. Survey of chronic pain in Europe: prevalence, impact on daily life, and treatment. Eur J Pain. 2006;10(4):287-333.

4. Byvaltsev V, Krutko A, Shepelev $V$ et.al. Results of staged surgical treatment of patients with tandem-stenosis of the cervical and lumbosacral spine. Hirurgia Pozvonochnika. 2017;14(2):50-62. (In Russian)

5. Brodke D, Annis P, Lawrence B, Woodbury AM, Daubs MD. Reoperation and revision rates of 3 surgical treatment methods for lumbar stenosis associated with degenerative scoliosis and spondylolisthesis. Spine (Phila Pa 1976). 2013;38(26):2287-94.

6. Afaunov A, Basankin I. Kuzmenko A, Shapovalov V. Complications of surgical treatment of degenerative lumbar stenosis. Hirurgia Pozvonochnika. 2016;13(4):66-72.

7. Prodan Al, Perepechay OA, Kolesnichenko VA, Balan SI, Chernyshev AG. Complications of surgical treatment for lumber spinal stenosis. Hirurgia Pozvonochnika. 2009;(1):31-7.

8. Handy AV, Shanko GG. Neuro-orthopedic and Orthopedic neurological syndromes in children and adolescents. Minsk: Harvest, 1998.

9. Kleinstueck FS, Diederich CJ, Nau WH, Puttlitz CM, Smith JA, Bradford DS et. al. Acute biomechanical and histological effects of intradiscal electrothermal therapy on human lumbar discs. Spine (Phila Pa 1976). 2001;26(20):2198-207. 